\title{
SCREENING NEW TRICHODERMA ISOLATES FOR ANTAGONISTIC ACTIVITY AGAINST SEVERAL PHYTOPATHOGENIC FUNGI, INCLUDING FUSARIUM SPP.
}

\author{
H. M. Tkalenko *, O. I. Borzykh, S. V. Horal, K. M. Barvas-Hremiakova, L. A. Janse \\ Institute of Plant Protection of NAAS, \\ 33, Vasylkivska Str., Kyiv, Ukraine, 03022 \\ E-mail:microbiometod@ukr.net
}

Received September 14, 2020 / Received November 03, 2020 / Accepted November 20, 2020

\begin{abstract}
Aims. To obtain and characterize new isolates of Trichoderma antagonistic to phytopathogenic fungi, including Fusarium spp., and 2) to determine their suitability for mass production under different cultivation conditions. Methods. Microbiological, cultural-morphological, statistical. Results. From plants affected by phytopathogenic fungi: cucumber (Cucumis sativus L.), tomato (Solanum lycopersicum L.), white cabbage (Brassica oleracea L.), winter wheat (Triticum aestivum L.), spring barley (Hordeum vulgare L.) in the Forest-Steppe of Ukraine (Kyiv region) 11 new Trichoderma isolates were obtained. Preliminary, morphological determination allocated five of them to $T$. viride (isolates CK, $165,27,49,35)$, two of them to T. koningii $(21,64)$ and four of them to $T$. longibrachiatum $(161,162,163,164)$. All isolates showed moderate to high antagonistic activity towards 8 phytopathogenic fungal species (Fusarium oxysporum, Fusarium solani, Alternaria cucumerina, Colletotrichum phomoides, Botrytis cinerea, Trichothecium roseum, Penicillium sp., Cladosporium fulvum). In a dual culture experiment they showed generally similar or often higher activity to the above-mentioned fungi than the 8 control strains used in our study, belonging to T. viride (5 strains), T. koningii (2 strains) and T. harzianum (1 strain), which have been maintained since long time in our laboratory. The most active new isolate $\mathrm{CK}$, (presumably) T. viride, showed comparable high activity towards all phytopathogenic fungi as compared to our most active control strain of T. viride, no. 23. The latter is the basis of a biocide Trichodermin, produced by biolaboratories of Ukraine, including the Institute of Plant Protection, NAAS, Kyiv. Chlamydospore production of all isolates and strains studied in submerged culture varied from $10^{6}$ to $3 \cdot 10^{7}$ spores $/ \mathrm{ml}$, were T. viride isolates and strains were on the higher end. Isolates of ' $T$. longibrachiatum' did not produce chlamydospores in submerged culture. Upon superficial cultivation on barley grain, the strains and isolates of T. viride were also characterized by the highest production of spores $\left(6 \cdot 10^{9}-9 \cdot 10^{9} \mathrm{spores} / \mathrm{g}\right)$ as compared to those of $T$. koningii, T. harzianum $\left(5.5 \cdot 10^{9}-6.8 \cdot 10^{9} \mathrm{spores} / \mathrm{g}\right)$ and T. longibrachiatum $\left(1.3 \cdot 10^{8}-6.8 \cdot 10^{8} \mathrm{spores} / \mathrm{g}\right)$. In an in-vivo experiment under laboratory conditions the most promising antagonistic isolate CK was used to inoculate wheat seed and tested for protection against Fusarium root rot (inoculum a mixture of $F$. avenaceum, F. culmorum, F. gibbosum, F. oxysporum, in $4 \cdot 10^{4}$ spores $/ \mathrm{g}$ ), where it gave an $83 \%$ reduction in root rot as compared to the non-inoculated control. Conclusions. Five new isolates preliminarily (on the basis of morphological characteristics only) allocated to T. viride and four to $T$. longibrachiatum demonstrated in vitro the highest and widest antagonistic activity against the phytopathogenic fungal species Fusarium oxysporum, Fusarium solani, Alternaria cucumerina, Colletotrichum phomoides, Botrytis cinerea, Trichothecium roseum, Penicillium sp., Cladosporium fulvum, as compared to new isolates, preliminarily allocated to $-T$. harzianum and $T$. кoningii. New isolate CK (allocated to $T$. viride) showed a promising and similar high antagonistic activity as compared to our T. viride 23 strain, which is already successfully used in the biocide Trichodermin. Since this isolate CK also produced a high number of chlamydospores in submerged culture $\left(3 \cdot 10^{7}\right.$ spores $\left./ \mathrm{ml}\right)$ and conidia $\left(8 \cdot 10^{9}\right.$ spores $\left./ \mathrm{g}\right)$ when surface cultured on barley grain respectively, it is a potential new candidate for a biocide. When this CK isolate was studied in a small laboratory pot experiment, to control $F u$ sarium root rot in wheat by preventive seed inoculation, it caused an $83 \%$ reduction in this Fusarium root rot. Its usefulness under field conditions and its effect on growth of plants will be investigated in future research.
\end{abstract}

Key words: mass production, submerged and surface cultivation, biological control.

DOI: https://doi.org/10.15407/agrisp7.03.014

(C) H.M. TKALENKO, O.I. BORZYKH, S.V. HORAL, K.M. BARVAS-HREMIAKOVA, L.A. JANSE, 2020 


\section{INTRODUCTION}

Trichoderma fungal species are worldwide and in all climate zones an essential part of the microflora in all types of soils, both in terrestrial and marine ecosystems (Klein, Eveleigh, 1998). They occur commonly in the rhizosphere, but can also colonize (as endophytes) aboveground plant parts.

Recent investigations have shown that Trichoderma spp. can sense, penetrate and kill other fungi and this has led to the development of a large number of successful biopesticides with Trichoderma spp. as basis (Benitez T et al, 2004; Harman GE et al, 2005; Schuster, Schmoll, 2010; Kubicek CP et al, 2011; Błaszczyk et al, 2014; Sawant IS, 2014; Sood et al, 2020).

Trichoderma spp. produce a wide spectrum of (volatile) antibiotics killing a number of fungi and nematodes. Their metabolites, including enzymes are able to stimulate plant growth, to induce resistance in plants against pathogens and induce abiotic stress tolerance and are used in industrial processes (Mastouri $\mathrm{F}$ et al, 2010; Lorito et al, 2010; Contreras-Cornejo HA et al, 2011; Sawant IS, 2014; López-Bucio J et al, 2015; Fiorentino $\mathrm{N}$ et al, 2018). Some Trichderma spp are noxious, because they are pathogenic to humans (Sandoval-Denis SA et al, 2014) and cultivated mushroom (Goltapeh EM, Danesh YR, 2006).

In addition to high antagonistic potential, the fungi of this genus are notable for good growth rate and the possibility of cultivating on non-expensive substrates, thus, they are widely used in the elaborations of biological preparations in industrial conditions. The cultivation of Trichoderma fungi is done both superficially using loose substrates (Cavalcante RS et al, 2008, Motta FL et al, 2012), and by the submerged technology in liquid culture media (Jakubíková L et al, 2006; Šimkovič $\mathrm{M}$ et al, 2008; Al-Taweil HI et al, 2009; Kobori NN et al, 2015; Ferdous Akter M et al, 2018).

Biofungicides, based on Trichoderma spp. were presented worldwide in 2014 by over 250 products and comprised about $60 \%$ of the international market of biofungicides. The most common species in most products, based on Trichoderma, is T. harzianum (83\%), followed by T. viride, and and T. koningii (Woo et al, 2014). $T$. harzianum and $T$. viride are mainly used to treat soil for about 87 different crops against 70 soil pathogens and 18 foliar pathogens, predominantly fungi such as Verticillium spp., Fusarium spp., Rhizoctonia solani, Sclerotinia sclerotiorum, Alternaria radicina, Pythium spp, and Botrytis cinerea (Topolovec-Pintarić, S., 2019).
Biopreparations are highly effective against root rots, wilts of vegetables, grown in covered soil (Liu JB et al, 2009; Lorito $\mathrm{M}$ et al, 2010; Pill et al, 2011; Yang X et al, 2011; Borrero et al, 2012; Kakvana N et al, 2013; Abo-Elyousr et al, 2014; El Komy MH et al, 2015; Adhikary M et al, 2017; Bunbury-Blanchette AL, 2019; Rivera-Méndez W, 2020).

The aims of our study were 1) to obtain and characterize new isolates of Trichoderma antagonistic to phytopathogenic fungi, including Fusarium spp., and 2) to determine their suitability for mass production under different cultivation conditions.

\section{MATERIALS AND METHODS}

The studies were conducted in the Laboratory of Microbiological Methods of Plant Protection at the Institute of Plant Protection, NAAS, Kyiv in 2015-2019.

Trichoderma fungi were isolated from plants affected by phytopathogenic fungi: cucumber (Cucumis sativus L.), tomato (Solanum lycopersicum L.), white cabbage (Brassica oleracea L.), winter wheat (Triticum aestivum L.), spring barley (Hordeum vulgare L.) in the Forest-Steppe of Ukraine (Kyiv region) (Table 1). Isolates were obtained by transferring germinated conidia, which appeared on the surface of parts of plants affected by phytopathogenic fungi, to wort agar medium.

Preliminary allocation of the new isolates to a Trichoderma species was done on the basis of morphological features only, following the keys of Gams W and Bissett J, (2002).

The antagonistic activity of 11 new isolates and 8 collection strains of Trichoderma (kept for 30 years in the Laboratory of Microbiological Methods of Plant Protection at the Institute of Plant Protection, NAAS) (see Table 2) was determined by the method of blocks the dual culture assay, using different species of phytopathogenic fungi, isolated by us from diseased plant material and maintained as agar slants in our culture collection (Table 2) - Fusarium oxysporum (isolated from the roots of cucumbers), Fusarium solani (isolated from a tomato stalk), Alternaria cucumerina (isolated from the leaves of cucumbers), Colletotrichum phomoides (isolated from the fruit of the tomato), Botrytis cinerea (isolated from the fruit of the cucumber), Trichothecium roseum (isolated from soybean seeds, Glycine max (L) Merr), Penicillium sp. (isolated from soybean seeds), and Cladosporium fulvum (isolated from cucumber leaves). 
TKALENKO et al.

The strains of phytopathogenic fungi (Table 2) were grown in Erlenmeyer flasks on an orbital shaker (PSU20i, Biosan, Latvia) in liquid wort medium for $72 \mathrm{~h}$ at $200 \mathrm{rpm}$ and $25^{\circ} \mathrm{C}$ in the dark. Inoculum for flasks was obtained by rinsing with sterile water spore-mycelial mass from the surface of agar in test tubes. One $\mathrm{ml}$ of liquid culture of each phytopathogenic strain was added to a Petri dish and mixed with $15 \mathrm{ml}$ of wort agar. Trichoderma isolates and strains under investigation were grown in Petri dishes using wort agar for 5 days at $25{ }^{\circ} \mathrm{C}$. Agar blocks ( $5 \mathrm{~mm}$ diam.) were cut out with a cork borer from the margins of 7-day-old colonies and placed into the Petri dishes with the just seeded phytopathogenic fungi, 3 blocks per Petri dish, in equal distance from each other. Incubation was for 5 days at $25{ }^{\circ} \mathrm{C}$ in an incubator (TS-80, Czech Republic).

The antagonistic activity was determined in the dual culture assay on day 5 of the experiment by measuring the growth inhibition zones of test objects using the following scale: inhibition zone $0 \mathrm{~mm}$, inactive; $1-$ $14 \mathrm{~mm}$ poor activity; $15-25 \mathrm{~mm}$ moderate activity; $>26 \mathrm{~mm}$ strong activity. The dual culture assay was done in three repeats.

The technological suitability for mass production of the new Trichoderma isolates was determined by submerged and surface cultivation using chlamydospore formation and biomass production as indices.

Submerged cultivation was done in $300 \mathrm{ml}$ Erlenmeyer flasks with $50 \mathrm{ml}$ of medium on a rotary shaker (200 rpm) at $25-26{ }^{\circ} \mathrm{C}$ for $72 \mathrm{~h}$ in the medium, using corn extract (side product of starch and syrup production, PrJSC 'Dneprovsky Starch and Syrup Integrated Works', Dniprovske, Dnipropetrovskyi region) and beet molasses (side product of sugar beet production, PrJCT 'Salyvonkivskyi Sugar Plant', Hrebinky, Kyiv region): corn extract $-1 \%$; molasses $-3 \%$; $\mathrm{NH}_{4} \mathrm{NO}_{3}-0.5 \% ; \mathrm{KH}_{2} \mathrm{PO}_{4}$ anhydrous - $0.5 \%$; $\mathrm{MgSO}_{4} \cdot 7 \mathrm{H}_{2} \mathrm{O}-0.2 \%$. (Tkalenko AN, Goral SV, 2013). Flasks with medium were sterilized in an autoclave at $0.1 \mathrm{MPa}$ for 30 minutes. Inoculation of flasks was performed with 7-day cultures grown in test tubes. The inoculum concentration was $5 \cdot 10^{6}$ spores $/ \mathrm{ml}$.

Surface cultivation was done in 1 L Erlenmeyer flasks with barley seeds. The flasks were filled with substrate to $1 / 3$ volume, moistened with water (70$80 \%$ by weight) and sterilized in an autoclave at 0.1 $\mathrm{MPa}$ for 30 minutes. Inoculation of flasks was performed with 7-day cultures grown in test tubes. The inoculum concentration was $1 \cdot 10^{6}$ spores/g. (Bondarenko et al, 1985) Cultivation was performed for 10 days till massive formation of air-distributed conidia at $25-26{ }^{\circ} \mathrm{C}$ occurred.

To determine the biomass of Trichoderma fungi, 10 $\mathrm{ml}$ of liquid culture was filtered through a paper filter (pore size 4-7 $\mu \mathrm{M}$ ), washed with distilled water and dried in an drying oven at $110{ }^{\circ} \mathrm{C}$ for 1 hour. The biomass was determined by weighing using a precision scale (Axis, Poland). The productivity of fungal spore formation was determined via direct calculation of spores in a Goryaev's chamber (haemacytometer with $90 \mathrm{~nL}$ capacity instead of the usual $100 \mathrm{~nL}$ ) with a microscope (Zeiss Primo Star, $\times 400)$.

The calculation of optimal inoculum doses of a liquid biopreparation based on isolate T. viride CK $(3.5 \times$ $\times 10^{7}$ chlamydospores $/ \mathrm{ml}$ ) was done using the pretreatment of winter wheat seeds of Myronivska 808

Table 1. Culture number and sources of isolation of new Trichoderma isolates from Kyiv region

\begin{tabular}{l|l}
\hline $\begin{array}{c}\text { Provisional species allocation and } \\
\text { collection number of isolate }\end{array}$ & \multicolumn{1}{c}{ Source of isolate } \\
\hline $\begin{array}{l}\text { T. viride CK } \\
\text { T. viride } 165\end{array}$ & $\begin{array}{l}\text { cucumber roots affected by root rot } \\
\text { stem of a tomato plant affected by Fusarium wilt } \\
\text { T. viride } 27\end{array}$ \\
$\begin{array}{l}\text { T. viride } 49 \\
\text { T. viride } 35\end{array}$ & $\begin{array}{l}\text { leaves of white cabbage, affected by phytopathogens } \\
\text { cucumber roots affected by root rot }\end{array}$ \\
T. koningii 21 & roots of winter wheat affected by root rot \\
T. longibrachiatum 161 & tomato affected by root rot \\
T. longibrachiatum 162 & roots of winter wheat affected by root rot \\
T. longibrachiatum 163 & roots of spring barley affected by root rot \\
T. longibrachiatum 164 & roots of spring barley affected by root rot \\
\end{tabular}




\section{SCREENING NEW TRICHODERMA ISOLATES FOR ANTAGONISTIC ACTIVITY AGAINST SEVERAL}

variety (as it is nationally widely cultivated) in three concentrations $(0.04,0.2,1 \%)$. For this experiment, performed under laboratory conditions, artificial inoculated sterilized potting soil was used. The experiment was performed in plastic containers the size $50 \times 40 \times 10 \mathrm{~cm}$. The soil was inoculated with a mixture of four Fusarium spp. (F. avenaceum, F. culmorum, $F$. gibbosum, F. oxysporum, cultivated in wort medium for $72 \mathrm{~h}$ on an orbi-tal shaker, $200 \mathrm{rpm}$ ) in a final concentration of $4 \cdot 10^{4}$ spores/g soil. Winter wheat seeds were soaked in suspensions of liquid culture of T. viride CK for 2 hours and sown 100 seeds per container. The containers were kept at room temperature and natural light. The experiment was done in three repeats.

Results of studies. During our studies (2015-2019) 11 Trichoderma isolates were obtained (Table 1) and on the basis of the morphologically characteristics we made a presumptive species identification: $T$. viride, isolates CK, 165, 27, 49, 35; T. koningii, isolates 21, 64; T. longibrachiatum, isolates 161, 162, 163, 164.

It was determined that the 11 new Trichoderma isolates differed in their antagonistic activity against the eight phytopathogenic fungi tested (Table 2). In general, the solates, morphologically allocated to $T$. viride and T. longibrachiatum showed a higher activity and broader spectrum of action than the isolates allocated to $T$. harzianum and T. koningii.

Seven out of ten investigated isolates and strains of $T$. viride $(23, \mathrm{CK}, \mathrm{Tp}-1,75,27,49,35)$ demonstrated high antagonistic activity regarding all fungal spp. tested, both in producing antibiotic substances and in hyperparasitic activity with the build-up of phytopathogen colonies and abundant spore formation (Table 2). Isolate $T$. viride $\mathrm{CK}$ showed the highest activity apart from the control strain for this species, T. viride 23 (Fig. 1).

Table 2. The antagonistic activity of 11 newly obtained isolates of Trichoderma and control strains for the species T. viride, T. koningii and T. harzianum

\begin{tabular}{|c|c|c|c|c|c|c|c|c|}
\hline \multirow[b]{2}{*}{$\begin{array}{c}\text { Species and number of } \\
\text { isolate/strain }\end{array}$} & \multicolumn{8}{|c|}{ Diameters of growth inhibition zones of phytopathogenic fungi, $\mathrm{mm} ; \mathrm{n}=3$} \\
\hline & 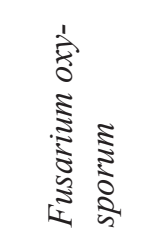 & 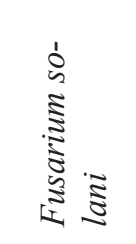 & 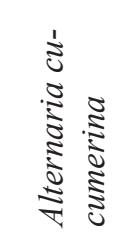 & 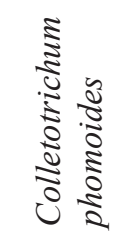 & 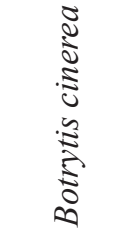 & 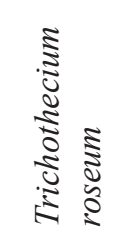 & 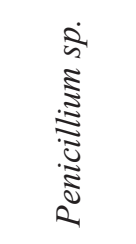 & 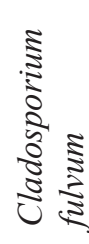 \\
\hline T. viride 23 & $36 \pm 3.0$ & $40 \pm 0$ & $>50$ & $>50$ & $>50$ & $>50$ & $>50$ & $>50$ \\
\hline T. viride CK (new) & $40 \pm 7.54$ & $30 \pm 3.2$ & $>50$ & $48 \pm 1.7$ & $>50$ & $>50$ & $38 \pm 1.7$ & $>50$ \\
\hline T. viride 165 (new) & $16 \pm 8.6$ & $15 \pm 2.6$ & $50 \pm 9.6$ & $>50$ & $50 \pm 8.0$ & $5 \pm 0.9$ & $31 \pm 6.8$ & 0 \\
\hline T. viride $\mathrm{Tp} 1$ & $>50$ & 25 & $49 \pm 5$ & $>50$ & $>50$ & $>50$ & $22 \pm 4$ & $>50$ \\
\hline T. viride 75 & $>50$ & 25 & $>50$ & $>50$ & $>50$ & $>50$ & $35 \pm 4$ & $>50$ \\
\hline T. viride 27 (new) & $>50$ & 15 & $>50$ & $>50$ & $>50$ & $>50$ & $31 \pm 3$ & $>50$ \\
\hline T. viride 49 (new) & $>50$ & 20 & $49 \pm 2$ & $>50$ & $>50$ & $>50$ & $15 \pm 2$ & $>50$ \\
\hline T. viride35 (new) & $40 \pm 5$ & 25 & $>50$ & $>50$ & $>50$ & $>50$ & $23 \pm 1$ & $>50$ \\
\hline T. viride $\mathrm{TM}$ & $0 \pm 0$ & 0 & $12 \pm 4$ & 26 & 25 & $25 \pm 5$ & $0 \pm 0$ & 20 \\
\hline T. viride $\mathrm{T} 3$ & $10 \pm 2$ & 0 & $25 \pm 6$ & 20 & 25 & $43 \pm 4$ & $21 \pm 4$ & 30 \\
\hline T. koningii M10 & $0 \pm 0$ & 0 & $6 \pm 6$ & 21 & 15 & $22 \pm 3$ & $5 \pm 1$ & 15 \\
\hline T. koningii 21 (new) & $15 \pm 3$ & 10 & $15 \pm 3$ & 33 & 18 & $24 \pm 3$ & $0 \pm 0$ & 10 \\
\hline T. koningii 64 (new) & $20 \pm 2$ & 10 & $18 \pm 4$ & 27 & 24 & $22 \pm 1$ & $8 \pm 1$ & 10 \\
\hline T. harzianum 8900 & $45 \pm 5$ & 25 & $35 \pm 7$ & 42 & 45 & $40 \pm 10$ & $30 \pm 2$ & 40 \\
\hline T. harzianum 8995 & $58 \pm 5$ & 20 & $40 \pm 7$ & 48 & 43 & $>50$ & $20 \pm 4$ & 38 \\
\hline T. longibrachiatum 161 (new) & $17 \pm 5.0$ & $5 \pm 0.7$ & $>50$ & $>50$ & $>50$ & $>50$ & $20 \pm 3.2$ & $>50$ \\
\hline T. longibrachiatum 162 (new) & $17 \pm 5.0$ & $5 \pm 0.3$ & $>50$ & $>50$ & $>50$ & $>50$ & $25 \pm 2.9$ & $>50$ \\
\hline T. longibrachiatum 163 (new) & $24 \pm 1.9$ & 0 & $50 \pm 0$ & $>50$ & $>50$ & $30 \pm 0$ & $13 \pm 3.3$ & $>50$ \\
\hline T. longibrachiatum 164 (new) & $19 \pm 1.9$ & 0 & $>50$ & $>50$ & $>50$ & $40 \pm 0$ & $16 \pm 0.9$ & $>50$ \\
\hline
\end{tabular}

Note. Data presented as mean values \pm standard error. 


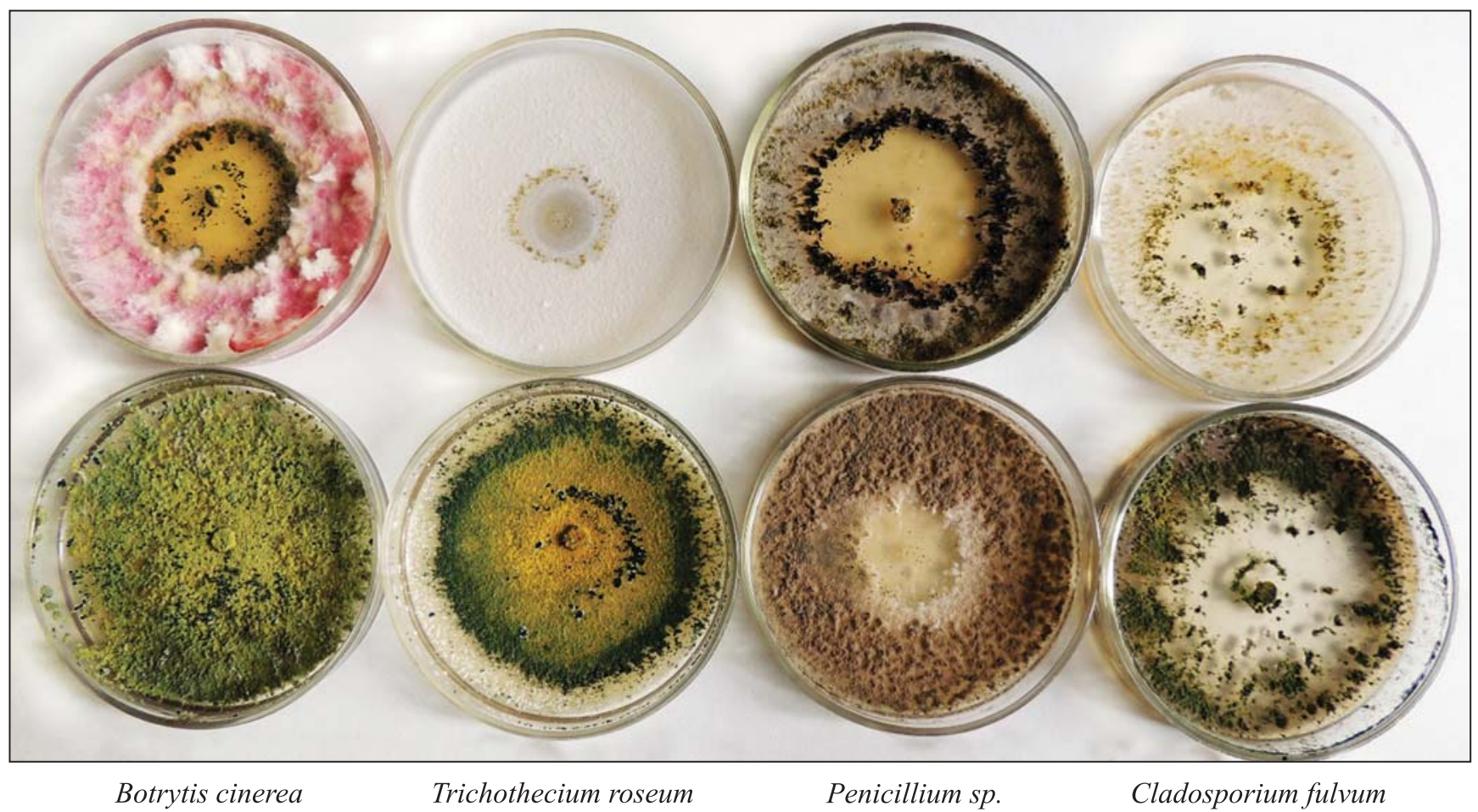

Fig. 1. Growth inhibition of different phytopathogenic fungi by a new isolate of presumptive $T$ viride (T. viride CK) on wort agar, 7 days after co-incubation at $25^{\circ} \mathrm{C}$ in the dark

Isolate T. viride 165 demonstrated much lower antagonistic activity regarding two Fusarium species (2-2.5 times smaller diameters of the growth inhibition zones of phytopathogens compared with isolate $T$. viride $\mathrm{CK}$ and strain T. viride 23), and this isolate did not inhibit the growth of Trichothecium roseum and Cladosporium fulvum.

Some of our laboratory strains showed rather disappointing results concerning antagonism of some phytopathogenic fungi: high activity of the $T$. viride T-3 strain was found only against Trichothecium roseum, as for Alternaria cucumerina, Colletotrichum phomoides, Botrytis cinerea, Penicillium sp., Cladosporium fulvum, it had moderate activity against $F$. oxysporum and no activity against Fusarium solani. T. viride TM demonstrated poor antagonistic activity against Alternaria cucumerina, Colletotrichum phomoides, Botrytis cinerea, Cladosporium fulvum, and did not inhibit the growth of F. oxysporum, F. solani, Penicillium sp.

Both laboratory strains of T. harzianum demonstrated high antagonistic activity, inhibiting the growth of all the investigated species of phytopathogenic fungi.

The isolates of $T$. longibrachiatum showed also a good antagonistic activity, except against both Fusarium spp. tested.
The isolates and control strains of T. koningii were characterized by low to moderate antagonistic activity only against all fungal spp. tested.

Under submerged cultivation conditions in liquid corn extract/molasse medium, all 19 investigated isolates and strains produced almost a similar amount of biomass over a period of 72 hours cultivation at $25^{\circ} \mathrm{C}$, namely 10.2-14.7 g/l (Table 3).

All studied strains and isolates of $T$. viride (Fig.2), T. harzianum and T. koningii produced chlamydospores in the submerged culture.

Spore formation productivity of the new isolate $T$. viride CK was on the level of the biocide Trichodermin control strain $T$. viride 23 , namely $3 \cdot 10^{7}$ chlamydospores $/ \mathrm{ml}$ after 72 hours growth in corn extract/molasse medium at $25{ }^{\circ} \mathrm{C}$. Other isolates and strains of $T$. viride produced a smaller amount of chlamydospores, $1.0 \cdot 10^{7}-1.5 \cdot 10^{7} / \mathrm{ml}$. The productivity of $T$. harzianum strains was $8 \cdot 10^{6}$ chlamydospores/ $\mathrm{ml}$. A considerably smaller number of chlamydospores was produced by the $T$. koningii control strain and the two new isolates $-0.7 \cdot 10^{6}-1.4 \cdot 10^{6}$ chlamydospores $/ \mathrm{ml}$.

The new isolates of $T$. longibrachiatum did not produce chlamydospores in the submerged culture (Fig. 3). 
Under surface cultivation on barley seeds, T. viride isolates and strains were characterized by higher productivity compared to strains of the other three species (T. koningii, T. harzianum, T. longibrachiatum of aerial spores (conidia) - 6.2 $10^{9}-9.2 \cdot 10^{9} \mathrm{spores} / \mathrm{g}$, and only two strains of this species (TM and T-3) produced a smaller number of conidia, viz. $3.8 \cdot 10^{9}$ $4.3 \cdot 10^{9}$ spores $/ \mathrm{g}$. The productivity of $T$. koningii and $T$. harzianum control strains was on the level of $5.5 \cdot 10^{9}-6.8 \cdot 10^{9} \mathrm{spores} / \mathrm{g}$, and the productivity of conidia formation in the four new $T$. longibrachiatum isolates was the lowest, namely $1.3 \cdot 10^{8}-6.8 \cdot 10^{8}$ spores/g. T. longibrachiatum isolates were notable for later formation of spores (by 7-10 days) as compared to $T$. viride strains and isolates.

The treatment of seeds with a preparation with $T$. viride isolate $\mathrm{CK}$ in a $1 \%$ concentration decreased the infection of plants with root rots by $83 \%$ as compared to the control. After twenty-fold decrease in the preparation concentration the biological efficacy decreased twice (40\%), see Table 4.

\section{DISCUSSION}

Mass production of biological control preparations requires the availability of initial strains with high antagonistic activity and specific, suitable growth characteristics: high productivity, synchronic growth (biomass) and spore formation. Due to observed loss of their initial antagonistic traits, physiological features, change in morphological characteristics, once active strains may show lower or zero activity after long-term storage and subculturing on artificial media. Therefore, existing industrial strains of microorganisms require periodic check-up by the main indices - sporulation rate, technological specificities, activity rate.

This study was aimed at estimating the antagonistic activity and suitability for cultivation of 19 Trichoderma spp. isolates and strains - 11 new isolates and 8 collection strains, the latter have been maintained by us for a long time and used to produce biopreparation Trichodermin.

Trichoderma spp. strains produce different types of propagula - mycelium fragments, conidia (air-

Table 3. Biomass and spore production of 11 newly obtained Trichoderma isolates and control strains of T. viride, T. koningii and T. harzianum and isolates of T. longibrachiatum under submerged and surface cultivation conditions

\begin{tabular}{|c|c|c|c|}
\hline \multirow{2}{*}{$\begin{array}{l}\text { Species and number } \\
\text { of the strain }\end{array}$} & \multicolumn{2}{|c|}{ Submerged cultivation } & \multirow{2}{*}{$\begin{array}{l}\text { Surface cultivation, aerial } \\
\text { spore production } \times 10^{9} / \mathrm{g}\end{array}$} \\
\hline & biomass, g/l & $\begin{array}{c}\text { chlamydospores } \\
\text { production } \times 10^{6} / \mathrm{ml}\end{array}$ & \\
\hline T. viride 23 & $14.7 \pm 0.7$ & $32.4 \pm 3.7$ & $7.8 \pm 0.7$ \\
\hline T. viride СК (new) & $13.7 \pm 0.5$ & $31.6 \pm 3.2$ & $7.9 \pm 0.5$ \\
\hline T. viride 165 (new) & $11.6 \pm 0.7$ & $15.3 \pm 0.33$ & $6.2 \pm 0.5$ \\
\hline T. viride $\mathrm{Tp} 1$ & $12.1 \pm 0.9$ & $9.5 \pm 0.45$ & $8.4 \pm 0.5$ \\
\hline T. viride 75 & $12.7 \pm 0.7$ & $9.7 \pm 0.70$ & $7.2 \pm 0.4$ \\
\hline T. viride 27 (new) & $10.9 \pm 0.1$ & $10.4 \pm 0.11$ & $8.1 \pm 0.7$ \\
\hline T. viridee 49 (new) & $12.2 \pm 0.5$ & $9.7 \pm 0.70$ & $7.9 \pm 0.3$ \\
\hline T. viride 35 (new) & $13.0 \pm 0.2$ & $11.5 \pm 1.0$ & $9.2 \pm 1.0$ \\
\hline T. viride TM & $11.7 \pm 0.8$ & $10.2 \pm 0.6$ & $4.3 \pm 0.3$ \\
\hline T. viride T 3 & $10.5 \pm 0.6$ & $9.9 \pm 1.23$ & $3.8 \pm 0.7$ \\
\hline T. koningii M10 & $11.1 \pm 0.4$ & $0.7 \pm 0.12$ & $5.4 \pm 0.8$ \\
\hline T. koningii 21 (new) & $11.3 \pm 0.7$ & $1.4 \pm 0.33$ & $6.8 \pm 1.1$ \\
\hline T. koningii - 64 (new) & $11.5 \pm 0.7$ & $1.1 \pm 0.05$ & $6.2 \pm 1.0$ \\
\hline T. harzianum 8900 & $10.2 \pm 1.1$ & $7.8 \pm 0.62$ & $5.5 \pm 0.4$ \\
\hline T. harzianum 8995 & $12.1 \pm 0.7$ & $8.0 \pm 0.31$ & $5.9 \pm 0.7$ \\
\hline T. longibrachiatum-161 (new) & $11.8 \pm 0.3$ & not produced & $0.13 \pm 0.02$ \\
\hline T. longibrachiatum-162 (new) & $14.5 \pm 0.2$ & not produced & $0.22 \pm 0.01$ \\
\hline T. longibrachiatum-163 (new) & $13.9 \pm 0.7$ & not produced & $0.68 \pm 0.04$ \\
\hline T. longibrachiatum-164 (new) & $14.2 \pm 0.3$ & not produced & $0.17 \pm 0.01$ \\
\hline
\end{tabular}

Note. Data presented as mean values \pm standard error. 


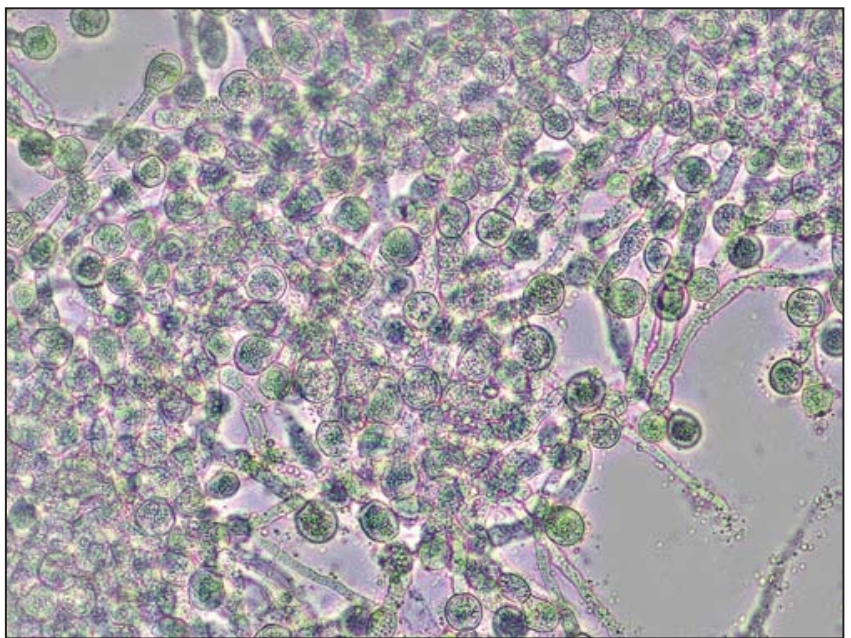

Fig. 2. The growth of T. viride $\mathrm{CK}$ in the submerged culture (after 72 hours growth in corn extract/molasse medium at $25^{\circ} \mathrm{C}$ ) producing chlamydospores

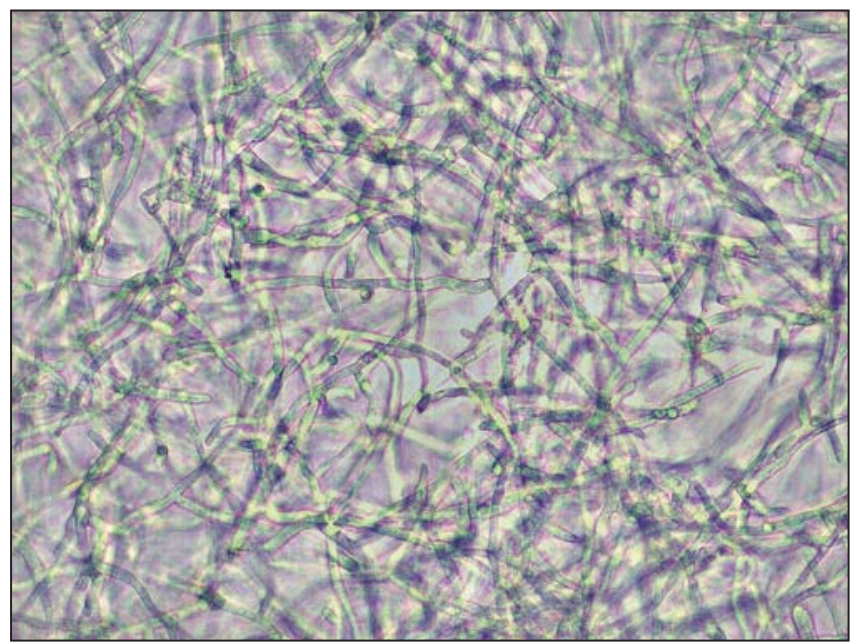

Fig. 3. The growth of $T$. longibrachiatum in the submerged culture (after 72 hours growth in corn extract/molasse medium at $25^{\circ} \mathrm{C}$ )

Table 4. Determination of the effective dose of a Trichodermin biological preparation, based on new $T$. viride isolate $\mathrm{CK}$, for pre-sowing treatment of winter wheat seeds

\begin{tabular}{c|c}
\hline $\begin{array}{c}\text { Content of preparation } \\
\text { in a working suspension, \% } \\
\text { of a } 3 \cdot 10^{7} \text { spores } / \mathrm{ml} \\
\text { concentrate in liquid } \\
\text { culture }\end{array}$ & $\begin{array}{c}\text { The decrease in the number } \\
\text { of plants, infected with root } \\
\text { rot, \% (as compared } \\
\text { to the control) on day } 12, \\
\mathrm{n}=3\end{array}$ \\
\hline 1.00 & $82.9 \pm 4.73$ \\
0.20 & $57.2 \pm 5.34$ \\
0.04 & $40.0 \pm 3.91$ \\
\hline
\end{tabular}

Data presented as mean values \pm standard error distributed or submerged), chlamydospores (submerged) with different biological efficacy or storage stability (Lewis JA, Papavizas GS, 1984). Most biopreparations of Trichoderma spp. are produced using air-distributed conidia, formed on moistened grain of cereals via solid-phase fermentation (Motta FL et al, 2014; Woo et al, 2014; Cruz-Quiroz RD et al, 2017; Hamrouni $\mathrm{R}$ et al, 2019).

Submerged cultivation has several advantages, including shorter period of cultivation and the possibility of automation of many operations. Since not all the fungi are capable of spore formation in the submerged culture, the selection of the corresponding strain is of utmost significance (Jakubíková L. et al, 2006).

Submerged conidia, produced by some strains of Trichoderma spp., have thinner cell wall compared to air-distributed conidia and lower survival rate while stored (Watanabe S et al, 2006). Chlamydospores are suggested as the most promising propagules to produce preparations using the submerged technology, as they are capable of surviving in soil for a long time, having faster germination in soil and lower sensitivity to soil fungistasis than conidia. Chlamydospore-based formulations have other beneficial features, including resistance to drying and low temperatures, insensitivity to soil antibiotics, and extended preservation time, which in turn simplifies processing, storage, and transport of the biological control agent (Beagle-Ristaino JE, Papavizas GC, 1985; Li et al, 2016).

The ability of the investigated Trichoderma strains to produce chlamydospores in the submerged culture (spores of vegetative reproduction), which are the forms in the cycle of fungus development, most resistant to the impact of unfavorable environmental factors, ensuring their survival in soil, is the prerequisite for the elaboration of the submerged technology of liquid preparation production.

Therefore, following the results of our initial laboratory assessment, the new $T$. viride $\mathrm{CK}$ isolate was selected for further studies, as it is the most promising candidate for a microbiological preparation, judging by its antagonistic activity and technological traits under submerged cultivation. Growth characteristics of T. viride isolate $\mathrm{CK}$ after incubation of 5 days on wort agar at $25^{\circ} \mathrm{C}$ are shown in Fig. 4.

The suitability of Trichoderma spp. isolates and strains for mass cultivation was determined by the indices of conidia formation during superficial cultivation on grain and the capability of producing chlamydo- 

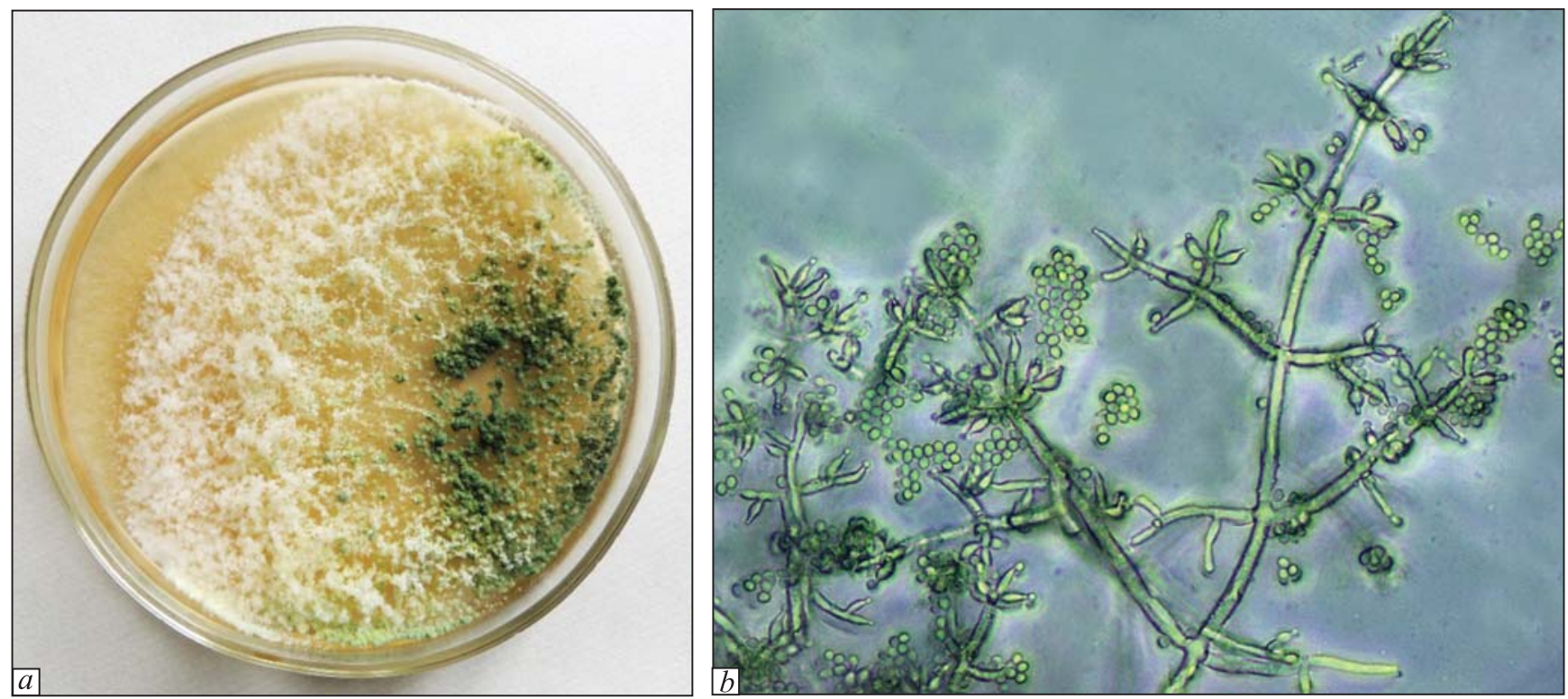

Fig. 4. T. viride CK strain: $a$ - growth after cultivation of 5 days at $25{ }^{\circ} \mathrm{C}$ on wort agar; $b$ - conidiophores and conidia of the fungus

spores in the submerged culture. Submerged cultivation was conducted using a culture medium, based on cheap organic sources of nutrients - corn extract and molasses, which can completely meet the demands of fungi for necessary nutrients and are economically reasonable, being by-products of food industry. Optimization of the culture medium, selection of the components and determination of their optimal content for the cultivation of the new $T$. viride isolate CK will be a further direction of our research.

T. viride isolate $\mathrm{CK}$, a promising highly antagonistic isolate in vitro, also showed promising antagonistic activity towards Fusarium spp. (reduced the number of plants affected by root rot by more than $80 \%$ ) when tested in a small laboratory based experiment where its effect on the reduction of root rot in wheat, variety Myronivska 808 , was investigated.

In our earlier studies, we tested a preparation based on the $T$. viride $\mathrm{CK}$ isolate in the field using cucumber. Pre-treatment of cucumber seeds hybrid Courage F1 at a rate of $2 \mathrm{ml} / \mathrm{kg}$ provided complete protection against plant loss during the seedling phase as a result of root rot caused by Fusarium spp. in the greenhouse (BalvasHremiakova K, 2019).

We also found that in addition to the protective effect, the $T$. viride $\mathrm{CK}$ isolate also demonstrated its growth-stimulating activity, increasing the germination by $20-25 \%$, furthermore metabolites, synthesized this isolate, stimulated growth activity of meristem cells - the length of the root and stem of cu- cumber plants was $25-30 \%$ larger during the seedling phase as compared to the control (Balvas-Hremiakova K and Goral S, 2019).

\section{CONCLUSIONS}

Five new isolates preliminarily (on the basis of morphological characteristics only) allocated to $T$. viride and four allocated to T. longibrachiatum, demonstrated in vitro the highest and widest antagonistic activity against the phytopathogenic fungal species Fusarium oxysporum, F. solani, Alternaria cucumerina, Colletotrichum phomoides, Botrytis cinerea, Trichothecium roseum, Penicillium sp., Cladosporium fulvum, as compared to new isolates, preliminarily allocated to T. harzianum and T. кoningii. New isolate CK (allocated to $T$. viride) showed a promising and similar high antagonistic activity as compared to our $T$. viride 23 strain, which is already successfully used in the biocide Trichodermin. Since this isolate CK also produced a high number of chlamydospores in submerged culture $\left(1 \cdot 10^{7}-3 \cdot 10^{7}\right.$ spores $\left./ \mathrm{ml}\right)$ and conidia $\left(6 \cdot 10^{9}-9 \cdot 10^{9} \mathrm{spores} / \mathrm{g}\right)$ respectively when surface cultured on barley grain, it is a potential new candidate for a biocide. When this CK isolate was studied in a small laboratory pot experiment, to control $F u$ sarium root rot in wheat, by preventive seed inoculation, it caused an $83 \%$ reduction in this Fusarium root rot. Its usefulness under field conditions and its effect on growth of wheat plants will be investigated in future research. 
Adherence to ethical principles. All experiments described in this paper were non animal based.

Conflict of interest. Authors declare no conflict of interest.

Financing. This study was not financed by any specific grant from financing institutions in the state, commercial or non-commercial sectors.

\section{Скринінг нових ізолятів Trichoderma на антагоністичну активність щодо кількох фітопатогенних грибів, у тому числі Fusarium spp.}

Г. М. Ткаленко *, О. І. Борзих, С. В. Гораль, К. М. Бальвас-Гремякова, Л. А. Янсе

Інститут захисту рослин НАAН

вул. Васильківська, 33, Київ, Україна, 03022

E-mail: microbiometod@ukr.net

Мета. Отримати та охарактеризувати нові ізоляти Trichoderma 3 антагоністичними властивостями відносно фітопатогенних грибів - збудників хвороб пшениці, у тому числі Fusarium spp. та визначити їх придатність для масового виробництва в різних умовах вирощування. Методи. Мікробіологічні, культурально-морфологічні, статистичні. Результати. 3 рослин, уражених фітопатогенними грибами: огірок (Cucumis sativus L.), помідор (Solanum lycopersicum L.), білокачанна капуста (Brassica oleracea L.), озима пшениця (Triticum aestivum L.), ярий ячмінь (Hordeum vulgare L.) у Лісостепу України (Київська область), виділено 11 нових ізолятів Trichoderma. За культурально-морфологічними характеристиками п'ять 3 них були визначені як T. viride (ізоляти СК, 165, 27, 49, $35)$, два - T. koningii $(21,64)$, чотири $-T$. longibrachiatum $(161,162,163,164)$. Усі ізоляти виявляли помірну та високу антагоністичну активність щодо 8 видів фітопатогенних грибів (Fusarium oxysporum, Fusarium solani, Alternaria cucumerina, Colletotrichum phomoides, Botrytis cinerea, Trichothecium roseum, Penicillium sp., Cladosporium fulvum). У експерименті з подвійною культурою вони виявили загалом подібну або в деяких випадках вищу активність до вищезазначених грибів, ніж 8 контрольних штамів, використаних у нашому дослідженні, що належать до T. viride (5 штамів), T. koningii (2 штами) та T. harzianum (1 штам), які тривалий час підтримуються в мікробіологічній лабораторії Інституту захисту рослин НААН. Найактивніший новий ізолят СК, визначений як T. viride, проявив високу активність відносно всіх фітопатогенних грибів порівняно $з$ високоактивним контрольним штамом $T$. viride 23, який є продуцентом біопрепарату Триходерміну, що виробляється біолабораторіями України, в тому числі Інституту захисту рослин НААН (Київ). Продуктивність утворення хламідоспор всіх ізолятів та штамів, що вивчалась при глибинному культивуванні, коливалась від $10^{6}$ до $3 \cdot 10^{7}$ спор/мл, при цьому ізоляти та штами T. viride мали найвищу продуктивність спороутворення. Ізоляти 'T. longibrachiatum' не утворювали хламідоспор у глибинній культурі. При поверхневому вирощуванні на зерні ячменю штами та ізоляти $T$. viride також характеризувалися найвищою продуктивністю спороутворення $\left(6 \cdot 10^{9}-9 \cdot 10^{9}\right.$ спор/г) порівняно з $T$. koningii, T. harzianum $\left(5,5 \cdot 10^{9}-6,8 \cdot 10^{9}\right.$ спор/г) та $T$. longibrachiatum $\left(1,3 \cdot 10^{8}-6,8 \cdot 10^{8}\right.$ спор/г). В експерименті in vivo в лабораторних умовах найбільш перспективний антагоністичний ізолят СК був використаний для передпосівної обробки насіння пшениці на штучному інфекційному фоні, створеному внесенням в грунт збудників кореневих гнилей (суміш Fusarium avenaceum, Fusarium culmorum, Fusarium gibbosum, F. oxysporum, $4 \cdot 10^{4}$ спор/г), знизивши ураження рослин кореневими гнилями на $83 \%$ порівняно з контролем. Висновки. П'ять нових ізолятів, попередньо (лише на основі морфологічних характеристик) ідентифіковані як T. viride, $\mathrm{i}$ чотири - T. longibrachiatum, проявили in vitro найвищу антагоністичну активність відносно фітопатогенних грибів Fusarium oxysporum, Fusarium solani, Alternaria cucumerina, Colletotrichum phomoides, Botrytis cinerea, Trichothecium roseum, Penicillium sp., Cladosporium fulvum, порівняно $з$ новими ізолятами, попередньо визначеними як T. harzianum i T. коningii. Новий ізолят CK (визначений як T. viride) показав високу антагоністичну активність, що була на рівні штаму $T$. viride 23 , який $є$ продуцентом біопрепарату Триходермін. Ізолят СК продукував велику кількість хламідоспор у глибинній культурі $\left(3 \cdot 10^{7}\right.$ спор/мл) та конідій при культивуванні на зерні ячменю (8 $10^{9}$ спор/г), і $є$ перспективним в якості продуцента біопрепарату. Передпосівна обробка насіння пшениці рідкою культурою ізоляту СК на штучному інфекційному фоні в лабораторних умовах знижувала ураження рослин фузаріозними кореневими гнилями на $83 \%$. Ефективність його застосування у польових умовах та вплив на ріст рослин будуть досліджені в майбутніх дослідженнях.

Ключові слова: масове виробництво, глибинне та поверхневе вирощування, біологічний захист.

\section{REFERENCES}

Abo-Elyousr KAM., Abdel-Hafez SII., Abdel-Rahim IR. (2014) Isolation of Trichoderma and evaluation of their antagonistic potential against Alternaria porri. J. Phytopathol. 162(9):567-574. doi: 10.1111/jph.12228.

Adhikary M, Begum H, Meah M. (2017). Possibility of recovering fusarium wilt affected eggplants by Trichoderma. International J. Agric. Res., Innovat. Technol. 7(1):38-42. doi: 10.3329/ijarit.v7i1.33319.

Al-Taweil HI, Bin Osman M, Hamid AA, Wan Yussof WM. (2009) Optimizing of Trichoderma viride cultivation in submerged state fermentation. Amer. J. Appl. Sci. 6(7):1284-1288. doi: 10.3844/ajassp.2009.1284.1288.

Balvas-Hremiakova K, Goral S. (2019) Stimulating activi- 
ty of metabolites fungi of the genus Trichoderma on plant growth. Young Scientist. 7(71):165-168. doi: 10. 32839/2304-5809/2019-7-71-34.

Balvas-Hremiakova K. (2019) The system of plant protection of cucumbers from root rot in greenhouses. Karantin i zahist roslin. 9-10:12-15. doi: 10.36495/23120614.2019.9-10.12-15.

Beagle-Ristaino JE, Papavizas GC. (1985). Survival and proliferation of Trichoderma spp. and Gliocladium (Trichoderma) virens in soil and in plant rhizospheres. Phytopathology. 75:729-732. https://www.apsnet.org/ publications/phytopathology/backissues/Documents/ 1985Articles/Phyto75n06_729.PDF.

Benitez T, Rincon AM., Limon MC., Codon AC. (2004) Biocontrol mechanisms of Trichoderma strains. Inter. Microbiol. 7:249-260. doi: 10.2436/im.v7i4.9480.

Bondarenko AI, Buymistru AD, Guliy VV, Nikols'ka SI et al., Ed. Guliy $V V$ Cultivation and application of fungi against pests and diseases in greenhouses. Methodical recommendations. Chisinau: VNIIBMZR, 1985:86 p.

Borrero C, Trillas M, Delgado A, Aviles M. (2012) Effect of ammonium/nitrate ratio in nutrient solution on control of Fusarium wilt of tomato by Trichoderma asperellum T34. Plant Pathol. 61(1):132-139. doi: 10.1111/j.13653059.2011.02490.x.

Bunbury-Blanchette AL, Walker AK. (2019) Trichoderma species show biocontrol potential in dual culture and greenhouse bioassays against Fusarium basal rot of onion. Biological Control. 130:127-135. doi: 10.1016/j. biocontrol.2018.11.007.

Blaszczyk L, Siwulski M, Sobieralski K. et al. (2014) Trichoderma spp. - application and prospects for use in organic farming and industry. J. Plant Protec. Res. 54(4):309-317. doi: 10.2478/jppr-2014-0047.

Cavalcante RS., Lima HLS., Pinto GAS. et al. (2008) Effect of moisture on Trichoderma conidia production on corn and wheat bran by solid state fermentation. Food and Bioproc. Techno. 1:100-104. doi: 10.1007/s11947-007-0034-x.

Contreras-Cornejo HA, Macías-Rodríguez L, Beltrán-Peña E, et al. (2011) Trichoderma-induced plant immunity likely involves both hormonal and camalexin-dependent mechanisms in Arabidopsis thaliana and confers re-sistance against necrotrophic fungi Botrytis cinerea. Plant Signal. Behav. 6(10):1554-1563. doi: 10.4161/psb.6.10.17443.

Cruz-Quiroz RD, Roussos S, Hernandez-Castillo D et al. (2017) Solid-state fermentation in a bag bioreactor: effect of corn cob mixed with phytopathogen biomass on spore and cellulase production by Trichoderma asperellum. In: Jozala A (eds) Fermentation processes. London, 43-56. doi: $10.5772 / 64643$.

El Komy MH, Saleh AA, Eranthodi A, Molan YY. (2015) Characterization of novel Trichoderma asperellum isolates to select effective biocontrol agents against tomato Fusarium wilt. Plant Pathol. J. 31(1):50-60. doi: 10.5423/ PPJ.OA.09.2014.0087.
Ferdous Akter M, Ahmed GU, Alam MF. (2018) Evaluation of modified air-lift photo bioreactor for quick mass production of Trichoderma harzianum. International J. Bas. Appl. Sci. 18(4). doi: 0.13140/RG.2.2.27509.63202.

Fiorentino N, Ventorino V, Woo SL, et al. (2018) Trichodermabased biostimulants modulate rhizosphere microbial populations and improve $\mathrm{N}$ uptake efficiency, yield, and nutritional quality of leafy vegetables. Front. Plant Sci. 9:743. doi: 10.3389/fpls.2018.00743.

Gams W, Bissett J. (2002) Morphology and identification of Trichoderma. In: Kubicek C.P., Harman G.E. (eds). Trichoderma and Gliocladium. Vol. 1. Taylor and Francis. London. 3-34. doi: 10.1201/9781482295320.

Goltapeh, EM, Danesh YR (2006). Pathogenic interactions between Trichoderma species and Agaricus bisporus. J. Agric. Technol. 2(1):29-37.

Hamrouni R, Molinet J, Mitropoulou G et al. (2019) From flasks to single used bioreactor: Scale-up of solid-state fermentation process for metabolites and conidia production by Trichoderma asperellum. J. Environ. Manag. 252:109496. doi: 10.1016/j.jenvman.2019.109496.

Harman GE, Björkman T. (2005) Potential and existing uses of Trichoderma and Gliocladium for plant disease control and plant growth enhancement. In: Kubicek C.P., Harman G.E. (eds). Trichoderma and Gliocladium. vol. 2. Taylor and Francis. London. 203-234. doi: 10. 1201/9781482267945.

Jakubiková L, Farkaš V, Kolarova N, Nemcovič M. (2006) Conidiation of Trichoderma atroviride isolate during submerged cultivation in a laboratory stirred-tank fermenter. Folia Microbiologica. 51(3):209-213. doi: 10. 1007/BF02932124.

Kakvana N, Heydarib A, Zamanizadeha HR et al. (2013) Development of new bioformulations using Trichoderma and Talaromyces fungal antagonists for biological control of sugar beet damping-off disease. Crop Protection. 53:80-84. doi: 10.1016/j.cropro.2013.06.009.

Klein D, Eveleigh DE. (1998) Ecology of Trichoderma. In: Kubicek C.P., Harman G.E. (eds). Trichoderma and Gliocladium. Vol. 1. Taylor and Francis. London. 57-74. doi: 10.1201/9781482295320.

Kobori NN, Mascarin GM, Jackson MA, Schisler DA. (2015) Liquid culture production of microsclerotia and submerged conidia by Trichoderma harzianum active against damping-off disease caused by Rhizoctonia solani. Fungal Biol. 119(4):179-190. doi: 10.1016/j.funbio. 2014.12.005.

Kubicek CP, Herrera-Estrella A, Seidl-Seiboth V. et al. (2011) Comparative genome sequence analysis underscores my-coparasitism as the ancestral lifestyle of Trichoderma. Genome Biol. 12:R40. doi: 10.1186/gb2011-12-4-r40.

Lewis JA, Papavizas GS. (1984) Chlamydospore formation by Trichoderma spp. in natural substrates. Canadian J. Microbiol. 30(1):1-7. doi: 10.1139/m84-001. 
TKALENKO et al.

Li Yq, Song K, Li Yc. et al. (2016) Statistical culture-based strategies to enhance chlamydospore production by Trichoderma harzianum SH2303 in liquid fermentation. J. Zhe-jiang Univ. Sci. 17:619-627. doi: 10.1631/jzus. B1500226.

Liu JB, Gilardi G, Gullino ML et al. (2009) Effectiveness of Trichoderma spp. obtained from re-used soilless substrates against Pythium ultimum on cucumber seedlings. J. Plant Dis. Prot. 116:156-63 doi: 10.1007/BF03356304.

López-Bucio J, Pelagio-Floresa R, Herrera-Estrella A. (2015) Trichoderma as biostimulant: exploiting the multilevel properties of a plant beneficial fungus. Scientia Horticulturae. 196:109-123.

Lorito M, Woo SL, Harman GE, Monte E. (2010) Translational research on Trichoderma: from 'Omics to the field. Ann. Rev. Phytopathol. 48:395-417. doi: 10.1146/annurevphyto-073009-114314.

Mastouri F, Björkman T, Harman GE. (2010) Seed treatment with Trichoderma harzianum alleviates biotic, abiotic, and physiological stresses in germinating seeds and seedlings. Phytopathology. 100:1213-1221. doi: 10.1094/ PHYTO-03-10-0091.

Motta FL, Santana MHA. (2014) Solid-state fermentation for humic acids production by a Trichoderma reesei strain using an oil palm empty fruit bunch as the substrate. Appl. Biochem. Biotechnol. 172:2205-2217. doi: 10.1007/s12010-013-0668-2.

Motta FL, Santana MHA. (2012) Biomass production from Trichoderma viride in non-conventional oat medium. Biotechnology Progress. 28(5):1245-1250. doi: 10.1002/ btpr.1578.

Pill WG, Collins CM, Gregory N, Evans TA. (2011) Application method and rate of Trichoderma species as a biological control against Pythium aphanidermatum (Edson) Fitzp. in the production of microgreen table beets (Beta vulgaris L.). Scientia Horticulturae. 129(4):914918. doi: 10.1016/j.scienta.2011.05.018.

Rivera-Méndez W. (2020) Trichoderma interactions in vegetable rhizosphere under tropical weather conditions. In: Sharma A., Sharma P. (eds) Trichoderma. Rhizosphere Biology. Springer, Singapore. p. 293-314. doi: 10.1007/ 978-981-15-3321-1_15.
Sandoval-Denis M, Sutton DA, Cano-Lira JF et al. (2014) Phylogeny of the clinically relevant species of the emerging fungus Trichoderma and their antifungal susceptibilities. J. Clin. Microbiol. 52(6):2112-2125. doi: 10. 1128/JCM.00429-14.

Sawant IS. (2014) Trichoderma - Foliar pathogen interactions. The Open Mycol. J. 8:58-70. doi: 10.2174/187 4437001408010058.

Schuster A, Schmoll M. (2010). Biology and biotechnology of Trichoderma. Appl. Microbiol. Biotechnoly. 87(3): 787-799. doi: 10.1007/s00253-010-2632-1.

Šimkovič M, Ditte P, Kurucová A et al. (2008) $\mathrm{Ca}^{2+}$-dependent induction of conidiation in submerged cultures of Trichoderma viride. Canad. J. Microbioly. 54(4): 291-298. doi: 10.1139/W08-001.

Sood M, Kapoor D, Kumar V et al. (2020) Trichoderma: The "Secrets" of a multitalented biocontrol agent. Plants. 9:762. doi: 10.3390/plants9060762.

Tkalenko A.N., Goral S.V. (2013) Optimization of parameters of submerged cultivation of the fungus genus Trichoderma. Zahist i karantin roslin. 59:311-318. http:// zkr.ipp.gov.ua/index.php/journal/issue/view/8/59-pdf. (in Ukrainian).

Topolovec-Pintarić, S. (2019) Trichoderma: Invisible partner for visible impact on agriculture. In Trichoderma - The Most Widely Used Fungicide; Manjur Shah, M., Sharif, U., Buhari, T.R., Eds.; IntechOpen: London, UK. 1-21. doi: 10.5772/intechopen.83363.

Watanabe S, Kato H, Kumakura K, Ishibashi E, Nagayama $K$. (2006) Properties and biological control activities of aerial and submerged spores in Trichoderma asperellum SKT-1. J. Pesticide Sci. 31(4):375-379. doi: 10.1584/ jpestics.G06-09.

Woo SL, Ruocco M, Vinale F et al. (2014) Trichodermabased products and their widespread use in agriculture. The Open Mycol. J. 8:71-126. doi: 10.2174/ 1874437001408010071.

Yang X, Chen L, Yong X et al. (2011) Formulations can affect rhizosphere colonization and biocontrol efficiency of Trichoderma harzianum SQR-T037 against Fusarium wilt of cucumbers. Biol. Fertil. Soils. 47:239-248. doi: 10.1007/s00374-010-0527-z. 